\title{
The International and
}

\section{Comparative Law Quarterly}

\section{VOLUME 5}

1956

William S. Hein \& Co., Inc.

Buffalo, New York

2003 
(c) British Institute of International and Comparative Law 1956. Published by Oxford University Press.

All rights reserved

This book has been digitally archived, to maintain the quality of the original work for future generations of legal researchers, by William S. Hein \& Co., Inc.

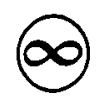

This volume is printed on acid-free paper by William S. Hein \& Co., Inc. 


\title{
Society of Comparative Legislation and International Law
}

\author{
CHAIRMAN OF THE EXECUTIVE COMMITTEE:
}

The Rt. How. Loen Justice Denwina

\section{COUNCIL :}

The Rt. Hon. Sir Sidney Abrahams.

Dr. B. R. Ambedkar.

M. Marc Ancel, Secrétaire Général de la Société de Législation Comparée.

Sir W. Bernard Blatch, Solicitor to the Inland Revenue.

The Rt. Hon. Viscount Bruce, Cr., s.c.

Sir John A. Calder, r.c.m.o.

Sir Cecil T. Carr, K.c.B., Q.C., Ix.D.

The Hon. Mr. Justice A. d. จ. S. Centlirres, Chief Justice of South Africa.

Dr. Futting Tien-Hsi Cheng, Lr.d.

Professor G. C. Cheshire, D.C.L., F.B.A.

J. Christie, Esq., cs.a., Lus.

The Rt. Hon. Sir Winston S. Churchill, K.a., o.m., C.H., M.P.

The Rt. Hon. Lord Cohen.

Professor René David, Faculté de Droit de l'Université de Paris.

Clement Davies, Esq., Q.c., M.P.

Neville Dixey, Esq., formerly Chairman of Lloyd's.

The Rt. Hon. Sir Owen Dixon, Chief Justice of Australia.

Sir Oscar Dowson, c.8.z, formerly Legal Adviser to the Home Offlce.

Sir Harold Duncan, k.c.x.o., a.c, formerly Legal Adviser to the Colonial Office and the Dominions Office.

The Rt. Hon. Lord Justice Denning.

The Rt. Hon. H. V. Evatt, D.LIm, L.D.

Phanor J. Eder, Esq.
The Hon. R. Feetham, c.m.a, formerly Judge of the Appellate Division of the Supreme Court of South Af rica.

E. G. M. Fletcher, Esq., ur.D., sx.P.

Sir R. R. Garran, K.c.m.a., Q.c., formerly Solicitor-General of the Commonwealth of Australia.

Professor Gerbrandy, formerly Prime Minister of the Netherlands.

Sir Lancelot Graham, x.c.8.1., x.c.1.8., formerly Secretary to the Government of India in the Legislative Department.

F. N. Keen, Esq.

The Hon. Mr. Justice Korsah, c.B.z.

The Hon. Ricardo de Labougle, LLD.

Judge Learned Hand.

Sir Lynden Macassey, R.B.z., Q.c.

Sir Henry MacGeagh, o.c.v.o., k.c. ., K.B.E., Q.c.

The Rt. Hon. Vincent Massey, Governor-General of Canada.

The Hon. Mr. Justice Northcroft, Judge of the Supreme Court, New Zealand.

The Rt. Hon. Lord Reld of Drem.

The Hon. L. A. Rajapaksa.

The Rt. Hon. T. Rinfret, formeriy Chicf Justice of Canada.

Sir J. S. Risley, E.c.s.o., c.8., Q.c, formerly Legal Adviser to the Colonial Office and Dominions Office.

The Rt. Hon. Louis J. St. Laurent, Prime Minister of Canada. 


\section{COUNCIL-continued}

The Hon. Mr. Justice Sandström.

Sir John Houldsworth Shaw, formerly Solicitor to the Inland Revenue.

The Hon. Mr. Justice Fabre-Surveyer, Judge of the Supreme Court, Quebec.
The Rt. Hon. Lord Thomson.

Sir Geoff rey Vickers, v.c.

Professor E. C. S. Wade, LL.D., Downing Professor of the Laws of England.

Professor B. A. Wortley, 0.B.E., IL.D.

\section{EXECUTIVE COMMITTEE :}

Sir W. Bernard Blatch.

"Sir Cecil T. Carr, k.c.B., Q.C., zL.D.

- Professor G. C. Cheshire, D.c.L., F.B.A.

The Rt. Hon. Lord Cohen.

J. Cohen, Esq., Hon. Treasurer.

-Dr. C. J. Colombos, a.c.

-The Rt. Hon. Lord Justice Denning, Chairman.

- Sir Harold Duncan, к.c.m.o., a.c.

Sir Gerald Fitzmaurice, к.c.m.o.

- Professor R. H. Graveson, LL.D., PII.D.

- Professor C. J. Hamson.

F. N. Keen, Esq.

William Latey, Esq., a.c.
-Professor F. H. Lawson, n.c.L.

R. A. Lynex, Esq.

Sir Lynden Macassey, K.в.z., Q.c.

-N. S. Marsh, Esq.

Richard O'Sullivan, Esq., Q.c.

Professor Sir David Hughes Parry, Q.c., D.c.l., LL.D.

Sir Kenneth Roberts-Wray, к.c.m.o.

-Dr. G. Schwarzenberger.

"Dr. C. Sluzewski.

Professor E. C. S. Wade, LL.D.

- Professor C. H. M. Waldock.

"E. H. Wall, Esq., r.o., Hon. Becretary.

-R. O. Wilberforce, Esq, Q.c.

-Professor B. A. Wortley, 0.B.2., LL.D.

Those marked are Members of the Editorial Sub-Committee.

The Editore and the Members of the Editorial Sub-Committee do not hold themseloes in any way responsible for the oiews expressed by contributors. 


\section{INDEX OF CONTRIBUTORS OF ARTICLES AND NOTES}

Aluen, Claud G., Revision of Geamay War-Time Judoments Uyder THE Bonn-Paris Agremert

Allott, A. N., The Effect of Marrjaue on Property in the Gold Coagt Anton, A. E., The Intronuction into Enalibh Paactice of Continental Theonieg in the Conflict of Lawb

“B.," The Cage op the Singapore Oil STocks

Blix, H., The Rule of Unayimity in the Revision of Treatigs 447, 881

Brom-Cooper, L. J., Extending the Bounds of Order XI

Brandon, Michael, Fifth Conference of the I.B.A.

Brown, D. J. Latham, The Etiriopia-Somaliland Frontiga Diaputz 245

Brown, L. Neville, The Sources of Spanibh Civic Law

Brownile, 1., Vowustegr8, War and Neutrality

Cons, Dr. E. J., The Fors of Wills of Immovables

Drucker, A., Soviet Corporations

Eichlea, Dr. W. E., Graman Caiminal Juriadiction

Gutrman, E., Pregumptions of Leoitimacy and Pateanity 217

Hambon, Prof. C. J., The Istanbul Confenence of 1955

Honio, F., Extradition gy Multilateral Convention

Jenks, C. W., International. Law and Activitieg in Space

Jonze, G. H., Adoption in the Conflict of Laws 207

Jonz8, J. M., The Notrebohm Case 230

Knox-MAwer, R., Defamation, some Indian Precedents 282

Iscamic Domestic Law in the Colony of Ades

“E. L.," European Coal and Steel Community Act, 1955 182

Agreement relating to the International Institute of Ref rigeration 184

Latey, W., Q.c., Juaisdiction in Divorce and Nullits

Lautegpacht, E., The Contemporary Panctice of the United Kinodom in the Fiet.d of International Law

Lrrize, R. E., Section 8 of Lord Kingsdown's Act and the Revocation of Wills

Loopea, R. B., Counterclaims against a Foreign Sovereign Plaintiff

Louggouarn, Prof. Y., Tire Faencil Draft on Paivate Imternational Law

Noke8, Prof. G. D., Codification oe tire Law of Evidence in Comonon

Law Jugibdictions

Paray, C., Further Congiderationg upon the Prince of Hanover'b Cabe 61

Reithmans, Dr. C., Payment of Waoes Durino Stoppaoe of Work 174

RusseL, M. J., Reciprocity in matrimonial jurisdiction 126

Schwex, E., The Austrian State Treaty and Human Rights 266

Simpsor, J. L., The Diverted Cargoes Arbitration 471

Sxirt, J. A. C., Machado v. Fontes revisited $\quad$ - 466

Spiro, Dr. E., Domicile of Minora Without Parents 196

Vouns, Prof. R., The Protection of the Accubed in Frencu Criminal Procedure 1, 157

W ATr8, A. D., Recent Decisions of the I.L.O. Administrative Tribunal 483 


\section{INDEX OF BOOK REVIEWS}

Bilfinger, C. (and others). Fontes Juris Gentium, Vol. A,II,8 : Decisions of German Superior Courts relating to International Law, 1945-1949

Gallardo, R. La Solution des Conflits de Lois dans les Pays de l'Amérique Latine: Divorce, Séparation de Corps, et Nullité du Mariage

Gluckman, M. The Judicial Process among the Barotse of Northern Rhodesia

Gruenhut, Dr. M. Juvenile Offenders before the Courts

Hoebel, E. A. The Law of Primitive Man

Hood Phillips, O. A First Book of English Law (3rd ed.)

Jackson, R. H. The Supreme Court in the American System of Government

Keeton, G. W. (and others). Current Legal Problems, 1955.

Koch, F. E. and Rothstein. J. La Convention Fiscale Franco-Brittanique du 14 décembre 1950 : Etude de l'application pratique

Lauterpacht, H. Annual Digest and Report of Public International Law

Lawson, F. H. A Common lawyer looks at the Civil law

Levy-Ullmann (various contributors). L'oeuvre juridique de LevyUllmann

Maxwell, W. H. and L. F. A Legal Biblography of the British Commonwealth of Nations, Vol. 1 : English Law to 1800 (2nd ed.)

A Repertory of Practice of the United Nations Organisation

St. John-Stevas, N. Obscenity and the Law

Schwartz, B. American Constitutional Law

Serick, R: Rechtsform und Realitaet Juristischer Personen

Silke, A. S. Income Tax in the Central African Federation

Srarlien, $O$. An Introduction to the Law of Nations

Tunc, A. and S. Le système constitutionnel des Etats Unis d'Amérique, Vols. I and II

Wade and Phillips. Constitutional Law (6th ed.)

Wiebringhaus, H. Das Gesetz der funktionellen Verdoppeiung

Yakemtchouk, R. L'O.N.U., La Sécurité Régionale et le Problème du Régionalisme

Zweigert, K. (and others). Europaeische Zusammenarbeit im Rechtswesen 


\title{
SUBJECT INDEX OF ARTICLES, NO'TES AND DECISIONS
}

\author{
1. PRIVATE INTERNATIONAL LAW
}

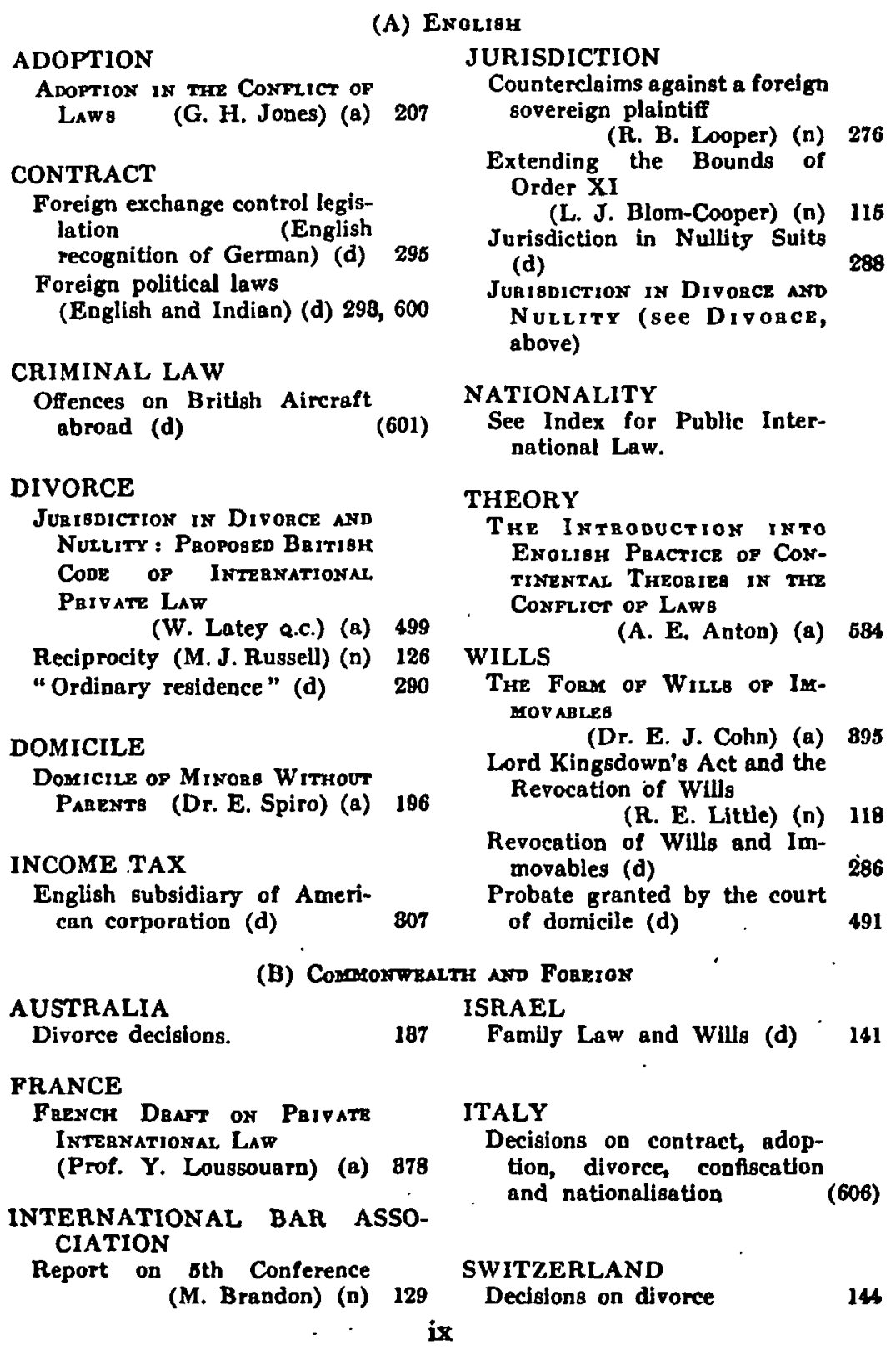




\section{COMPARATIVE LAW}

Contfication op thie Law of Evidence in Common Laf JUa18DICTION8

(Prof. G. D. Nokes) (a) 347

\section{ADEN \\ Iolamic Domegtic LaW it Tite Colony of AdEN \\ (R. Knox-Mawer) (a) 511

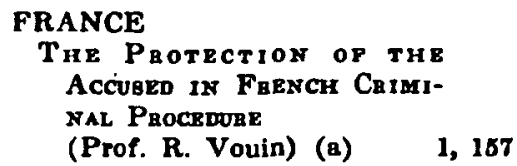

FRANCE, GERMANY, GREAT BRITAIN AND SWITZERLAND

Paegumptiong of Legitimacy and Paterintty abigino out OP LAWFUL WeDLock

(E. Guttmann) (a) 217

GERMANY

Copyright decisions, 1955

809
GERMANY-cont.

Graman Criminal JurigpicTION (Dr. W. E. Eichler) (a)

The Payment of Wabe Dunino Stoppace of Woak (Dr. C. Reithmann) (a)

GOLD COAST

The Effect of Marajace on PaOpenty in ThE Gold Const (A. N. Allott)

INDIA

Some Indian precedents on defamation and the Common law

\section{SPAIN}

The Sovaces of SPanibi Civir Law

(L. N. Brown) (a)

864

TURKEY

The Ibtanbus Confenence op 1980

(Prof. C. J. Hamson) (a)

\section{PUBLIC INTERNATIONAL LAW}

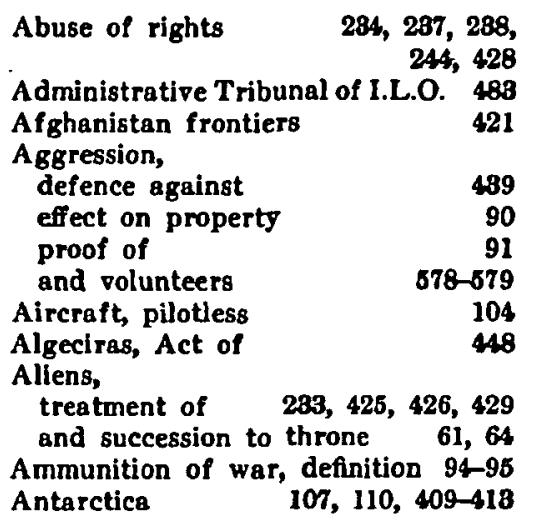

Belligerency, recognition of Belligerent occupation Belligerent rights, mitigation of

Cairo Declaration, 1948

Capitulations, in Tangier

Charter of United Nations, Art. 1 (8)

Art. 2 (7)
497,678 $84-98$ 88-89

413 461

Charter of United Nations-cont.

Art. 12 (I)

Art. 18 (1) (b)

486

Art. 65 (c)

266

Art. 76 (c)

266

Art. 81

266

Disarmament Committee $\quad 40$ and nuclear weapons 489

and territorial sovereignty $410-418$

Claurula robus sic stantibus 278

Committee of Privileges 74-76

Concession, and property rights 86-98

Confiscatory legislation $\quad 802$

Continuity of States $\$ 14$

Council of Europe 434, 549

Currency 426, 471

Cyprus, and human rights 492

Death penalty, and extradition

Denial of justice 56B- 664

426

230

$\begin{array}{lr}\text { Domestic jurisdiction } & 240 \\ \text { Dual nationality } & 64,66\end{array}$

Dual nationality

64

Estoppel 258

European Coal and Steel Community 


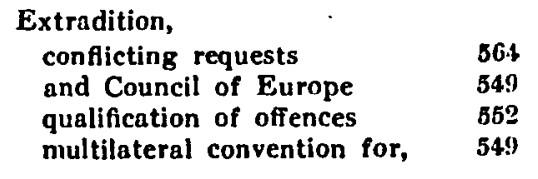

Fishing nets, convention on

Foreign Sovereign, and Royal Marriages Act

Formosa, status of

Freedom of the Seas, 102,429

Minorities, and Austria

Croat and Slovene whether minority treaties in force

Morocco, protectorate . 451

Most-favoured-nation clause $\quad 243$

Municipal law analogies

Nationality,

dual

effective

$280,231,242,243$

and extradition

238, 241, $242 n$.

fraudulently obtained

$558-660$

Hague Convention, $1930 \quad 235$

and protection 284

Nationality of claims 231

Nationality laws, conflict of 241

Naturalisation 61,230

Hague Conference on Private International Law 154, 155

Human Rights,

Neutrality, duty to defend 230

volunteers and $\mathbf{6 7 0}$

Austrian State Treaty and 265

European Convention on 266, 431 ,

Neutrals, duties in civil war

Nuclear weapons

Universal Declaration of

Occupation, belligerent

International Atomic Agency 108 res nullius, of

International Civil Aviation Organisation 107

International Court of Justice, 496, 441

International Institute of Refrigeration

International Labour Organisation,

Administrative Tribunal

International Tracing Service

Israel, blocked funds

Jerusalem, and United Nations

Jus sanguinis, and English law

Kamaran, title to

League of Nations, and minorities

Legislation, as source of international law

Mandate, proposed for Tangier 681

Marriage, Royal

Pakistan and State succession

Parliamentary answers

Political offences, and extradition

Potsdam Declaration, $1945 \quad 413$ $664-558$

Praemunire, statute of $\cdot$. 71-72

Prisoners of war, 274, 438

Prize court, belligerent rights and

Property, seizure in war $\quad 84$

Protectorate, meaning of 261

in Morocco 4.51

in Somaliland 245

Protest

42, 406

Quemoy, status of

Recognition of belligerency $\quad \mathbf{4 3 7}$

Red Cross

Refugees, convention on $\quad 659$

Requisition, of private property

Reservations, to treaties 
Security Council, effect of resolution

Self-determination

Self-protection, and activities in space

Somaliland, frontier dispute 245-264

Sovereignty,

in suspense

two meanings

United Nations, and

Space, status of

Specialised agencies of United Nations

Speciality, rule of 186

Specificatio, applied to refined oil

$86,92,98 \mathrm{n} ., 97$

Stateless persons, protection of 425

Statute,

effect of preamble

effect of antiquity

$61,62,64,65$

plain words rule

$64,65,66,67$

Subjects of international law 66

$\begin{array}{lr} & 244,262 \\ \text { Succession, to English throne } & 61 \\ \text { Succession of States } & 420-421 \\ \text { Suez Canal } & 485\end{array}$

Tangier,

1945 Agreement on 1952 Convention

688-688, 595

154, $690-692$

108-104

Territorial sovereignty

Territorial water 8 , Thames estuary

Territory,

administration by United

Nations.

409-413

dismemberment
'Territory-cont.

and planets 110

title to and protest 421

Treaties,

conflict of 253

as source of law $\quad 409$

succession of 414-421

with native tribes 254,261

Trieste 265, 412

Trust territory, administering

authority 411

Trusteeship system 111

Unanimity, and treaty revision

$447-465,581-596$

Unesco, and staff appointments 483

United Nations,

administration of territory $409-418$

personality of

$409-413$

See also Charter of United Nations.

United States Loyalty Board 484

Universal Postal Union 184

Osufruct, under Hague Regulations

Visas, abolition

445

Volunteers

$570-680$

War, and continuity of States $\$ 14$ and private property 84

War Damage claims $\quad \mathbf{2 0}$

War Damage Commission $\quad 84$

Weather station, on Betio $\mathbf{4 4 6}$

World Health Organisation 184, 164

World Meteorological Organisation 